\title{
Effect of fungicide on disease incidence and yield of bean (Phaseolus vulgaris L.) infected with Isariopsis griseola Sacc. and Ascochyta phaseolorum Sacc. ${ }^{1 / 2}$
}

\author{
Rocio Rodriguez and Pedro L. Meléndez ${ }^{3}$
}

\begin{abstract}
Two foliar diseases of beans, Phaseolus vulgaris L., namely angular leaf spot and ascochyta leat spot, caused by Isariopsis griseola and Ascochyta phaseolorum, respectively, were effectively controlled with chemicals. Biweekly applications of mancozeb and chlorothalonil (1.12, 2.48 and $4.48 \mathrm{~kg}$ / ha) effectively protected the foliage of bean cultivars Bonita and Naranjito against attacks by both pathogens. Cultivar Bonita responded better to treatments than cv. Naranjito in terms of yield. Some dosages of mancozeb and chlorothalonil increased yield of $\mathrm{cv}$. Bonita affected by angular leaf spot. Yield increases in plots treated with benomyl increased only when the highest rate of this chemical was used. Even at the lowest dosages, the three chemicals tested increased yield in cv. Bonita affected by the ascochyta leaf spot disease.
\end{abstract}

\section{INTRODUCTION}

Beans (Phaseolus vulgaris), which constitute a good source of inexpensive proteins, are an important component in the daily diet of large segments of the world poor. The demand for this legume increases as population increases, but its production is consistently constrained by several factors, the most limiting of which are diseases. Some plant diseases are usually very serious, while others are not always severe, but when conditions are favorable, the latter can reach epiphytotic proportions. Angular leaf spot and ascochyta leaf spot caused by Isariopsis griseola Sacc. and Ascochyta phaseolorum Sacc., respectively, are included in this group.

Angular leaf spot of beans is primarily a disease of the tropics and subtropics. Its presence has been reported from a wide range of bean production areas. Although the disease reduces the vitality of plants and lowers yields, Harter and Zaumeyer (9) reported that usually it is not of major economic importance. However, as often happens, increases in disease incidence are often observed to be closely associated with inten-

\footnotetext{
${ }^{3}$ Manuscript submitted to Editorial Board April 25, 1985.

${ }^{2}$ Research sponsored by USAID via Project for the Improvement of Tropical Production of Beans and Cowpeas through Disease and Insect Control (Contract AID/CM/ta-C-7326 and AID/TA-c-1296)

${ }^{3}$ Assistant Phytopathologist and Phytopathologist, respectively, Department of Crop Protection, College of Agricultural Sciences, University of Puerto Rico, Mayagüez, Puerto Rico 00708.
} 
sive cropping. Diaz et al. (5) in Venezuela, Barros et al. (1) in Colombia, Brock (2) in Australia, Cole (4) and Weaver and Zaumeyer (12) in the USA, reported heavy losses in bean production caused by $I$. griseola. Reductions in yield ranged from 10 to $50 \%$. These sporadic epiphytotics are the result of weather conditions. Hagedorn and Wade (8) considered that a prolonged warm and humid period, besides a good inoculum source, is needed for disease development.

Ascochyta leaf spot is a problem in the highlands. Similar to angular leaf spot, it is not considered a severe threat for bean production.

The accumulated knowledge of epiphytotics of minor diseases should not be overlooked. Chemical control measures for angular leaf spot and ascochyta leaf spot should be at hand to protect beans against unexpected attacks by these maladies.

\section{MATERIALS AND METHODS}

\section{ANGULAR LEAF SPOT}

Two field trials were established at the Adjuntas Substation in December 1977 and June 1978 to evaluate the foliar fungicides mancozeb, chlorothalonil and benomyl on bean cultivars Naranjito and Bonita for controlling angular leaf spot caused by Isariopsis griseola. Each of these chemicals was tested at three dosages: mancozeb and chlorothalonil at $1.12,2.24$ and $4.48 \mathrm{~kg} / \mathrm{ha}$; and benomyl at $0.28,0.60$ and $1.12 \mathrm{~kg} / \mathrm{ha}$. Mancozeb and chlorothalonil were applied weekly; benomyl, biweekly. Fungicide treatments were aimed at the foliage with a knapsack sprayer. The applications were initiated 3 weeks after planting, with a 7-day free harvest interval, making an average of four applications for benomyl and seven for chlorothalonil and mancozeb. The experimental layout consisted of a split-plot design with cultivars as whole plots and fungicide dosages as sub-plots. Treatments were replicated five times. Fach experiment consisted of $1009-\mathrm{m}^{2}$ plots. Fertilizer $10-10-8$ at the rate of 2.24 $\mathrm{kg} / \mathrm{ha}$ per row was applied at planting time. Weeds were controlled by hand until harvest. Periodic applications of Diazinon AG500 prevented insect damage. Yield and disease indexes, based on general appearance of plants in the two central rows, were recorded. Ratings based on percentage of diseased foliage were also recorded. Ratings based on percentage of disease symptoms $(1=1-20 \%, 2=21-40 \%, 3=41-60 \%$, $4=61-80 \%$ and $5=81-100 \%$ ) were recorded. Disease indices were calculated by means of the following equation:

$$
\text { DI }=\frac{\begin{array}{l}
\text { Sum of (disease class } \\
\times \text { number of plants in that class) }
\end{array}}{\begin{array}{c}
\text { Total Number of plants } \\
\times \text { Highest disease class }
\end{array}} \times 100
$$


Differences among treatments were submitted to analysis of variance and the means compared by multiple and orthogonal comparisons. Increments in yield were calculated by means of the following equation:

$\begin{aligned} & \text { Percentage of yield } \\ & \text { increment }\end{aligned}=\frac{\text { Yield of treated }- \text { yield of control }}{\text { Yield of control }} \times 100$

\section{ASCOCHYTA LEAF SPOT}

A trial was conducted in September 1978 in an attempt to control the ascochyta leaf spot on beans with chemicals. Experimental location,

TABLE 1.-Disease index and yield of bean cus Naranjito and Bonita treated with fungicides for controlling angular leaf spot (Isariopsis griseola), 1977

\begin{tabular}{|c|c|c|c|c|c|c|}
\hline \multirow{4}{*}{ Treatment } & \multicolumn{6}{|c|}{ Cultivar } \\
\hline & \multicolumn{3}{|c|}{ Naranjito } & \multicolumn{3}{|c|}{ Bonita } \\
\hline & Disease index & \multirow{2}{*}{ Yield } & \multirow{2}{*}{$\begin{array}{l}\text { Increase } \\
\text { in yield }\end{array}$} & Disease index & \multirow{2}{*}{ Yield } & \multirow{2}{*}{$\begin{array}{l}\text { Increase } \\
\text { in yield }\end{array}$} \\
\hline & 3 Mar 1977 & & & 3 Mar 1977 & & \\
\hline & & $k g / p l o t^{1}$ & $\%$ & & $\mathrm{~kg} / \mathrm{plot}^{\mathrm{I}}$ & $\%$ \\
\hline Mancozeb-1.12 kg/ha & $16^{* * 2}$ & 1.43 & 14.7 & $20^{* *}$ & 1.04 & 15.6 \\
\hline Mancozeb-2.24 kg/ha & $12^{* *}$ & 1.31 & 7.4 & $12^{* *}$ & $1.11^{* 3}$ & 23.3 \\
\hline Mancozeb-4.48 kg/ha & $0^{* *}$ & 1,21 & 0.8 & $24^{* *}$ & $1.07^{*}$ & 18.9 \\
\hline Chlorothalonil $-1.12 \mathrm{~kg} / \mathrm{ha}$ & $16^{* *}$ & 1.34 & 9.8 & $16^{* *}$ & 1.04 & 15.6 \\
\hline Chlorothalonil $-2.24 \mathrm{~kg} / \mathrm{ha}$ & $4^{* *}$ & 1.34 & 9.8 & $4^{* *}$ & $1.10^{*}$ & 22.2 \\
\hline Chlorothalonil $-4.48 \mathrm{~kg} / \mathrm{ha}$ & $8^{* *}$ & 1.26 & 3.3 & $0^{* * *}$ & 1.05 & 16.7 \\
\hline Benomyl- $0.27 \mathrm{~kg} / \mathrm{ha}$ & $24^{* *}$ & 1.42 & 16.4 & $28^{* *}$ & 1.05 & 16.7 \\
\hline Benomyl- $0.56 \mathrm{~kg} / \mathrm{ha}$ & $16^{* *}$ & 1,36 & 11.5 & $8^{* *}$ & 1.03 & 14.4 \\
\hline Benomyl-1.12 kg/ha & $12^{* *}$ & 1.39 & 13.9 & $4^{* *}$ & $1.12^{*}$ & 24,4 \\
\hline Check & 72 & 1.22 & - & 56 & 0.9 & - \\
\hline
\end{tabular}

Mean of 5 plots.

${ }^{2}$ Significantly different from the check at $\mathrm{P}=0.01$.

${ }^{3}$ Significantly different from the check at, $\mathrm{P}=0.05$.

layout, as well as chemicals, evaluated dosages, and agronomic practices were similar to those described for the above-mentioned angular leaf spot trials. Experimental plots were inoculated 2 and 4 weeks after planting. Inoculum was prepared by scraping the surface of 28-day old colonies of A. phaseolorum incubated at $28 \mathrm{C}$ on PDA (potato dextrose agar) petri plates to which $100 \mathrm{ml} /$ plate of Triton B-1956 $(0.06 \%)$ was added. Inoculum thus prepared was sprayed onto the foliage from a knapsack sprayer. Fungicidal applications were initiated 2 days before the first inoculation and discontinued 7 days before harvest. 


\section{RESULTS AND DISCUSSION}

\section{ANGULAR LEAF SPOT}

In the first experiment, established in mid December 1977, an attack by Isariopsis griseola occurred in the middle of the growing season. Nevertheless, all treatments effectively protected the foliage of both cultivars against the attack of this pathogen as evidenced by the damage on the check plants. However, in bean cv. Naranjito, regardless of the severe foliar damage on the check plots and of the effectiveness of all the fungicides tested, as expressed by low disease indexes, there were no significant yield differences among treatments (table 1). Conversely, in

TABLE 2.-Disease index and yield of bean cus Naranjito and Bonita treated with fungicides for controlling angular leaf spot (Isariopsis griseola), 1978

\begin{tabular}{|c|c|c|c|c|c|c|}
\hline \multirow{3}{*}{ Treatment } & \multicolumn{6}{|c|}{ Cultivar } \\
\hline & \multicolumn{3}{|c|}{ Naranjito } & \multicolumn{3}{|c|}{ Bonita } \\
\hline & Disease index & Yield & $\begin{array}{l}\text { Increase } \\
\text { in yield }\end{array}$ & Disease index & Yield & $\begin{array}{l}\text { Increase } \\
\text { in yield }\end{array}$ \\
\hline & & $k g / p l o t^{1}$ & $\%$ & & $\mathrm{~kg} / \mathrm{plot} \mathrm{t}^{1}$ & $\%$ \\
\hline Benomyl $-0.28 \mathrm{~kg} / \mathrm{ha}$ & $20^{* * 2}$ & 0.21 & 5 & $16^{* *}$ & 0.41 & 24 \\
\hline Benomyl $-0.56 \mathrm{~kg} / \mathrm{hg}$ & $20^{* *}$ & 0.18 & 10 & $12^{* *}$ & 0.43 & 30 \\
\hline Benomyl $-0.45 \mathrm{~kg} / \mathrm{ha}$ & $20^{* * *}$ & 0.27 & 35 & $8^{* * *}$ & 0.43 & 30 \\
\hline Chlorothalonil $-1.12 \mathrm{~kg} / \mathrm{ha}$ & $36^{* *}$ & 0.26 & 30 & $16^{* *}$ & $0.56^{* 3}$ & 70 \\
\hline Chlorothalonil- $2.24 \mathrm{~kg} / \mathrm{ha}$ & $16^{* *}$ & 0.32 & 60 & $16^{* *}$ & 0.32 & 3 \\
\hline Chlorothalonil $-4.48 \mathrm{~kg} / \mathrm{ha}$ & $16^{* * *}$ & $0.33^{*}$ & 65 & $12^{* *}$ & 0.44 & 33 \\
\hline Mancozeb-1.12 kg/ha & 48 & 0.22 & 10 & 24 & 0.40 & 21 \\
\hline Mancozeb-2.24 kg/ha & $36^{* *}$ & 0.26 & 30 & $12^{* *}$ & 0.51 & 54 \\
\hline Mancozeb-4.48 kg/ha & $20^{* * *}$ & 0.31 & 55 & $12^{* *}$ & $0.59^{*}$ & 79 \\
\hline Check & 60 & 0.20 & - & 32 & 0.33 & - \\
\hline
\end{tabular}

cv. Bonita some dosages of mancozeb, chlorothalonil and benomyl, increased yield as evidenced by significant differences when compared with yield of untreated plots (table 1).

In the second trial, yields were low, especially for cv. Naranjito, regardless of the treatments (table 2). This low yield was due mainly to heavy competition from Cyperus rotundus, which prevented normal vigorous plant development. However, disease expression was not affected, and again, all fungicides prevented serious foliar damage on both cultivars. Treatments with mancozeb and chlorothalonil were the most effective in increasing yield when compared to the check.

The analyses of variance of disease index for both trials showed 
significant differences among the overall means for treatments, and between fungicide treatments and the check (table 3). Except for cv. Naranjito in the trial, no significant differences for fungicides were detected. However, an effect of concentration was shown in all trials. A significant linear reduction in disease incidence with increased concentrations was observed. Thus concentrations are responsible for the detected differences among treatments and the check on disease incidence. This indicates that disease control can be obtained with all fungicides tested, but that their effectiveness depends on their concentrations.

In general, these cultivars behaved similarly in their response to treatments in reducing disease incidence; however, apparently cv. Naranjito is slightly more susceptible to angular leaf spot, according to the higher disease indexes recorded in plants from check plots (tables 1 and

TABLE 3. F values for disease index and yield in trials for the chemical control of angular and ascochyta leaf spot of beans

\begin{tabular}{|c|c|c|c|c|c|c|c|c|}
\hline \multirow{3}{*}{ Source of variation } & \multicolumn{4}{|c|}{1977} & \multicolumn{4}{|c|}{1978} \\
\hline & \multicolumn{2}{|c|}{ Bonita } & \multicolumn{2}{|c|}{ Naranjito } & \multicolumn{2}{|c|}{ Bonita } & \multicolumn{2}{|c|}{ Naranjito } \\
\hline & $\mathrm{DI}$ & Yield & DI & Yield & DI & Yield & $\mathrm{DI}$ & YieId \\
\hline Treatments 9 & $6.67^{* *}$ & $29.71^{* *}$ & $24.70^{* *}$ & 1.46 & $2.76^{*}$ & 1.41 & $12.24^{* * *}$ & 1.88 \\
\hline Fung. 2 & $2.67^{* *}$ & 0.04 & 3.89 & 1.27 & 0.55 & 0.78 & $7.75^{* *}$ & $3.37^{*}$ \\
\hline Cone. 2 & $3.98^{*}$ & 0.36 & $6.81^{* *}$ & 2.24 & 2.21 & 0.53 & $8.43^{* *}$ & 2.97 \\
\hline C. Lineal & $5.32^{*}$ & 0.63 & $13.14^{* *}$ & $4.46^{*}$ & $4.26^{*}$ & 0.22 & $16.25^{* *}$ & $5.88^{*}$ \\
\hline C. Quadratic & 2.65 & 0.08 & 0.49 & 0.02 & 0.16 & 0.84 & 0.60 & 0.07 \\
\hline Fung. vs Conc. & 1.35 & 0.46 & 0.97 & 0.78 & 0.43 & 1.83 & $2.78^{*}$ & 0.48 \\
\hline Fung, vs Control & $41.18^{* *}$ & $10.10^{* *}$ & $197.08^{* *}$ & 2.99 & $12.63^{* *}$ & 1.48 & $44.61^{* *}$ & 2.88 \\
\hline $\begin{array}{l}\text { Error for vari- } \\
\text { ance }\end{array}$ & 8.1244 & 21.0088 & 3.2888 & 25.9911 & 4.50372 & 7257.269 & 4.7259 & 948.2417 \\
\hline
\end{tabular}

2). Nevertheless, the results on the effects of treatments on yield were different.

Significant overall treatment mean differences, and interaction between treatments and the check for yield, were found for cv. Bonita in the 1977 trial, whereas in the 1978 trial, no effect of treatments was detected.

Cultivar Naranjito behaved differently. No differences in means of treatments for yield were found. Nevertheless, some effects of fungicides in increasing yield were evident. A significant linear effect of concentrations occurred, and depending on the year, negative and positive linear response in yield with increased concentrations were found.

These results indicate that in our trials, attack by $I$. griseola was not so early and severe as to cause significant yield losses on infected plants. 
Cardona and Walker (3) reported that infection by this pathogen is greatly favored by high humidity and temperatures from 16 to $28^{\circ} \mathrm{C}$, with an optimum at $24^{\circ} \mathrm{C}$.

Climatic conditions prevalent during the duration of the trials are summarized in table 4. Apparently, the environment was not at its optimum to induce formation of coremia and to enhance disease development. Nonetheless, our results suggest that these fungicides have great potential to protect beans from attack by $I$. griseola. Singh and Sharma (11) reported that four sprays of benomyl and mancozeb at 15-day intervals reduced angular leaf spot incidence. Similarly, Giroto (7) and

TABLE 4.-Climatological data for periods covered by experiments for the chemical control of Isariopsis griseola and Ascochyta phaseolorum on bean

\begin{tabular}{|c|c|c|c|c|c|}
\hline \multirow{2}{*}{ Month } & \multicolumn{3}{|c|}{ Temperature ${ }^{\circ} \mathrm{C}$} & \multirow{2}{*}{$\begin{array}{l}\text { Rain } \\
\mathrm{cm} \\
\text { mean }\end{array}$} & \multirow{2}{*}{$\begin{array}{c}\text { Relative } \\
\text { humidity } \\
\% \\
\text { mean }\end{array}$} \\
\hline & Mean Max & Mean Min & Mean & & \\
\hline \multicolumn{6}{|c|}{ Isariopsis } \\
\hline Dec & 26.7 & 14.2 & 20.6 & 0.08 & 73.8 \\
\hline Jan & 26.7 & 12.2 & 19.4 & 0.01 & 73.5 \\
\hline Feb & 27.0 & 13.4 & 20.2 & 0.30 & 73.0 \\
\hline March & 26.7 & 15.4 & 20.7 & 0.23 & 73.8 \\
\hline$\overline{\mathrm{X}}$ & 26.8 & 13.8 & 20.2 & 0.20 & 73.5 \\
\hline \multicolumn{6}{|c|}{ Isariopsis II } \\
\hline June & 29.3 & 16.7 & 23.0 & 0.36 & 75.5 \\
\hline July & 29.3 & 16.8 & 23.1 & 0.64 & 76.4 \\
\hline August & 27.9 & 17.2 & 23.2 & 0.51 & 75.1 \\
\hline$\overline{\mathrm{X}}$ & 28.8 & 16.8 & 23,1 & 0.51 & 75.1 \\
\hline \multicolumn{6}{|c|}{ Ascochyta } \\
\hline Sept. & 29.3 & 16.4 & 22.8 & 0.76 & 75.9 \\
\hline Oct. & 28.3 & 16.1 & 22.2 & 0.86 & 80.8 \\
\hline Nov. & 28.3 & 16.1 & 22.2 & 0.08 & 76.6 \\
\hline & 28.6 & 16.2 & 22.4 & 0.56 & 77.8 \\
\hline
\end{tabular}

Fortugno (6) were able to reduce disease incidence and significantly increase yield of beans with foliar applications of benomyl.

\section{ASCOCHYTA LEAF SPOT}

Good control of ascochyta leaf spot of beans was obtained with all fungicides tested. Both cultivars were equally susceptible to attack by the pathogen, although again $\mathrm{cv}$. Naranjito yielded less than $\mathrm{cv}$. Bonita and showed no significant differences in yield attributable to fungicide treatments (table 4). Even at the lowest dosages the three chemicals increased yield of cv. Bonita by more than $59 \%$ when compared with the check. 
The results of this trial indicate that $\mathrm{cv}$. Bonita can be effectively protected against attack by Ascochyta phaseolorum with any one of the fungicides evaluated (table 5). Since no significant differences for concentrations were detected, control can be obtained by using the lowest dosage tested, thus reducing the operational costs involved in fungicide applications. Linear reductions in disease incidence with increased con-

TABLE 5.-Disease index and yield of bean cus. Bonila and Naranjito treated with fungicides for controlling Ascochyta leaf spot

\begin{tabular}{|c|c|c|c|c|c|c|c|}
\hline \multirow[b]{2}{*}{ Treatment } & \multirow{2}{*}{$\underset{\text { Rate }}{\text { Ratha) }}$} & \multicolumn{3}{|c|}{ Bonita } & \multicolumn{3}{|c|}{ Naranjito } \\
\hline & & $\begin{array}{c}\text { Disease } \\
\text { index }\end{array}$ & $\begin{array}{l}\text { Yield } \\
\text { plot }^{1}\end{array}$ & $\begin{array}{l}\text { Increase } \\
\text { in yield }\end{array}$ & DI & $\begin{array}{l}\text { Yield/ } \\
\text { plot }^{1}\end{array}$ & $\begin{array}{l}\text { Increase } \\
\text { in yield }\end{array}$ \\
\hline & & & $k g$ & $\%$ & & $\mathrm{~kg}$ & \\
\hline Benomyl & 0.28 & $32^{* * 2}$ & $0.50^{* 3}$ & 51.5 & $28^{* *}$ & 0.31 & 11.4 \\
\hline Benomyl & 0.56 & $36^{* *}$ & $0.49^{*}$ & 48.5 & $28^{* *}$ & 0.38 & 8.6 \\
\hline Benomyl & 1.12 & $24^{* *}$ & $0.55^{* *}$ & 66.7 & $28^{* * *}$ & 0.42 & 20.0 \\
\hline Mancozeb & 1.12 & $28^{* *}$ & $0.50^{*}$ & 51.5 & $24^{* *}$ & 0.38 & 8.6 \\
\hline Mancozeb & 2.24 & $24^{* *}$ & $0.58^{* *}$ & 75.8 & $24^{* *}$ & 0.41 & 17.1 \\
\hline Mancozeb & 4.48 & $20^{* *}$ & $0.53^{* *}$ & 60.6 & $20^{* *}$ & 0.35 & 0.0 \\
\hline Chlorothalonil & 1.12 & $28^{* *}$ & $0.52^{*}$ & 57.6 & $20^{* *}$ & 0.36 & 2.9 \\
\hline Chlorothalonil & 2.24 & $24^{* *}$ & $0.52^{*}$ & 57.6 & $20^{* *}$ & 0.46 & 31.4 \\
\hline Chlorothalonil & 4,48 & $20^{* *}$ & 0.54 & 63.6 & $20^{* *}$ & 0.41 & 17.1 \\
\hline Check & - & 52 & 0.33 & - & 52 & 0.35 & - \\
\hline
\end{tabular}

${ }^{1}$ Mean of 5 plots.

${ }^{2}$ Significantly different from the check at $\mathrm{P}=0.01$.

${ }^{3}$ Significantly different from the check at $\mathrm{P}=0.05$.

TABLE 6.-F values for disease index and yield in trial for the chemical eontrol of Ascochyta phaseolorum on bean using orthogonal comparisons

\begin{tabular}{lccccc}
\hline \multirow{2}{*}{ Source of variation } & \multicolumn{2}{c}{ Bonita } & & \multicolumn{2}{c}{ Naranjito } \\
\cline { 2 - 3 } \cline { 5 - 6 } & DI & Yield & & DI & Yield \\
\hline Treatments & $4.45^{* * 1}$ & 1.84 & & $4.31^{* *}$ & 0.87 \\
Fungicides & 2.15 & 0.16 & & 2.30 & 0.64 \\
Concentrations & $2.6^{7}$ & 0.35 & & 0.08 & 1.58 \\
Linear & $4.66^{* 2}$ & 0.70 & & 0.12 & 1.06 \\
Quadratic & 0.69 & 0.01 & & 0.04 & 2.09 \\
Fung $\times$ Conc. & 0.34 & 0.41 & & 0.08 & 0.72 \\
Check vs Treated & $29.00^{* *}$ & $13.88^{* *}$ & & $33.71^{* *}$ & 0.52 \\
Variance for error & 4.1244 & 15.4811 & 4.32 & 13.8356 \\
\hline
\end{tabular}

${ }^{1}$ Significantly different at $\mathbf{P}=0.01$.

${ }^{2}$ Significantly different at $\mathrm{P}=0.05$.

centrations were detected without significant effect on yield. No significant effect on yield of fungicides and concentrations were shown on yield of cv. Naranjito (table 6).

No interaction between fungicides and concentrations was detected for either cultivar. However, a comparison with the check showed a significant effect of treatments in reducing disease incidence. 
Chemical control of Ascochyta phaseolorum has been recommended. Schwartz et al. (10) suggest benomyl and zineb as effective fungicides for the control of this disease in beans.

\section{RESUMEN}

Los fungicidas chlorothalonil, mancozeb y benomyl, protegieron eficazmente el follaje de los cultivares de habichuela Bonita y Naranjito contra el ataque de los hongos Isariopsis griseola y Ascochyta phaseolorum. El cv. Bonita mostró un incremento significativo en rendimiento como resultado de los tratamientos. Tanto mancozeb como chlorothalonil indujeron el aumento en rendimiento de Bonita cuando ésta fue atacada por ambos patógenos. Sin embargo, solamente la dosis más alta de benomyl (1.12 $\mathrm{kg} / \mathrm{ha}$ ) aumentó el rendimiento de la Bonita afectada por la mancha angular.

\section{LITERATURE CITED}

1. Barros, P., C. Cardona, R. Cardenosa and R. L. Skiles, 1958. Angular leaf spot of bean in Colombia, Plant Dis. Rep. 42: 420-24.

2. Brock, R. D., 1951. Resistance to angular leaf spot among varieties of beans, J. Austr. Inst. Agric. Sci. 17: 25-30; Rev. Appl. Mycol. Vol, 31.

3. Cardona, A. C. and J. C. Walker, 1956. Angular leaf spot of bean. Phytopathology 46: 610-15,

4. Cole, H., Jr., 1966. Angular leaf spot associated with severe defoliation of red kidney beans (Phaseolus vulgaris) in Pennsylvania, Plant Dis. Rep. 50: 494.

5. Diaz, P., C. E. de Armas and A. Barros, 1965. La mancha angular de la caraota producida por Iaariopsis griseola Sacc. en la cuenca del lago Valencia, Agron. Trop. (Maracay, Venez.) 14: 261-75.

6. Fortugno, C., 1977. Mancha angular (Isariopsis griseola Sacc.) en habichuela. IDIA No. 317/320; 26-33. EERA Salta, Argentina. (Abst. 2704). Rev. Plant Pathol. Vol. 57.

7. Giroto, R., 1976. Evaluación de fungicidas en el control de la antracnusis y de la mancha angular en poroto. IDIA No, 308:29-32. (Abst. $\# 5280)$ Rev. Plant Pathol. Vol. 56.

8. Hagedorn, D. J. and E. K. Wade, 1974. Bean rust and angular leaf spot in Wisconsin. Plant Dis. Rep. 58: 330-32.

9. Harter, I. L, and W. J. Zaumeyer, 1944. A monographic study of bean diseases and methods for their control. USDA Agric. Technol.

10. Schwartz, H., G. Gálvez, A. Schoonhoven, R. Howeler, P. Graham and C. Flor, 1978. Problemas de campo en los cultivos de frijol en América Latina, CIAT, Serie GS-19.

11. Singh, B. M. and R. Y. Sharma, 1977. Screening of fungicides to control angular and floury leaf spots of beans, Indin J. Mycol. Plant Pathol. (Abst. 1903 R.P.P.)

12. Weaver, L. O. and W. J. Zaumeyer, 1956. Angular leaf spot of bean found in Maryland, Plant Dis. Rep. 40: 1092. 